\title{
Isoprenoid Quinone Composition as a Guide to the Classification of Listeria, Brochothrix, Erysipelothrix and Caryophanon
}

\author{
By M. D. COLLINS, DOROTHY JONES \\ Department of Microbiology, School of Medicine and School of Biological Sciences, \\ University of Leicester, Leicester LE1 7RH \\ M. GOODFELLOW \\ Department of Microbiology, The Medical School, University of Newcastle-upon-Tyne, \\ Newcastle-upon-Tyne NE1 7RU \\ AND D. E. MINNIKIN \\ Department of Organic Chemistry, University of Newcastle-upon-Tyne, \\ Newcastle-upon-Tyne NE1 $7 R U$
}

(Received 28 November 1978)

\begin{abstract}
Representatives of the genera Brochothrix, Caryophanon and Listeria all contained fully unsaturated menaquinones as their sole isoprenoid quinones but Erysipelothrix rhusiopathiae contained neither menaquinones nor ubiquinones. Menaquinones with six isoprene units were the major isoprenologues in Caryophanon tenue whereas menaquinones with seven isoprene units predominated in Brochothrix thermosphacta, Listeria grayi, Listeria monocytogenes and Listeria murrayi. Listeria denitrificans had menaquinones with nine isoprene units.
\end{abstract}

\section{INTRODUCTION}

The taxonomic relationships of the genera Listeria, Erysipelothrix and Brochothrix present a number of unresolved problems.

The genera Listeria and Erysipelothrix were classified in the family Corynebacteriaceae by Breed et al. (1957) but subsequent numerical taxonomic studies (Davis et al., 1969; Stuart \& Pease, 1972; Jones, $1975 a$; Wilkinson \& Jones, 1977), DNA base ratio determinations (Flossmann \& Erler, 1972; Stuart \& Welshimer, 1973) and cell wall and peptidoglycan studies (Mann, 1969; Schleifer \& Kandler, 1972) have shown that they do not belong to the cornyeform group (Keddie, 1978). In the 8th edition of Bergey's Manual of Determinative Bacteriology (Buchanan \& Gibbons, 1974), both genera are treated with the genus Caryophanon as 'genera of uncertain affiliation' at the end of the section which includes the genus Lactobacillus.

The genus Brochothrix was proposed by Sneath \& Jones (1976) for bacteria previously designated Microbacterium thermosphactum (McLean \& Sulzbacher, 1953). The relationship of $M$. thermosphactum to $M$. lacticum, the type species of the genus Microbacterium, has always been controversial and more recent studies (see Collins-Thompson et al., 1972; Sneath \& Jones, 1976) indicate that the two species are sufficiently different to warrant the removal of $M$. thermosphactum from the genus Microbacterium.

Erysipelothrix and Brochothrix are both monospecific genera but Listeria presently contains four species, L. monocytogenes, L. denitrificans, L. grayi and L. murrayi (Seeliger 0022-1287/79/0000-8483\$02.00 (C) 1979 SGM 
\& Welshimer, 1974). While there is general agreement that $L$. denitrificans should be removed from the genus (Stuart \& Pease, 1972; Stuart \& Welshimer, 1973, 1974; Jones, $1975 a, b)$, there is no such agreement on the status of $L$. grayi and $L$. murrayi nor on the degree of their relationship to L. monocytogenes (Stuart \& Welshimer, 1974; Wilkinson \& Jones, 1977).

On the basis of a numerical taxonomic study, Wilkinson \& Jones (1977) suggested that the genera Listeria (excluding L. denitrificans), Erysipelothrix and Brochothrix should be classified in the family Lactobacillaceae together with the genera Lactobacillus, Gemella and Streptococcus. The main objection to this proposal is that bacteria of the genera Listeria and Brochothrix possess a haem-containing catalase and a functional cytochrome system (Friedman \& Alm, 1962; Davidson \& Hartree, 1968; Davidson et al., 1968; Meyer \& Jones, 1973; Jones, 1975 a), whereas members of the genera Erysipelothrix, Gemella, Lactobacillus and Streptococcus do not (see Buchanan \& Gibbons, 1974). However, Wilkinson \& Jones (1977) have discussed the occurrence of haem and non-haem catalases in streptococci and lactobacilli, and functional cytochromes have been reported in streptococci cultured under certain conditions (see Wilkinson \& Jones, 1977; Whittenbury, 1978).

Isoprenoid quinones play an important role in bacterial electron transport and possibly oxidative phosphorylation (Brodie \& Watanabe, 1966; Redfearn, 1966; Dunphy \& Brodie, 1971). In addition, recent studies have indicated the potential value of isoprenoid quinone analyses in the classification of coryneform and related bacteria (see Yamada et al., 1976; Collins et al., 1977, 1979; Minnikin et al., 1978a, b). In this study the distribution of isoprenoid quinones has been examined in representatives of the genera Listeria, Brochothrix and Erysipelothrix in an attempt to clarify their taxonomic position. A strain of Caryophanon tenue was included only because the genus Caryophanon is included in the same section as Listeria and Erysipelothrix in the 8th edition of Bergey's Manual of Determinative Bacteriology (Buchanan \& Gibbons, 1974).

\section{METHODS}

Cultures and cultivation. Details of the strains and their sources are given in Table 1. Organisms were maintained routinely on nutrient agar (Oxoid) and Dorset egg slopes at room temperature. Brochothrix, Caryophanon and Listeria strains were grown in shake culture at $30^{\circ} \mathrm{C}$ for 2 to $3 \mathrm{~d}$ in nutrient broth [10 $\mathrm{g}$ Neutralised Bacteriological Peptone (Oxoid L34), $8 \mathrm{~g} \mathrm{Lab}$ Lemco (Oxoid L29) and $5 \mathrm{~g} \mathrm{NaCl}$ in 11 distilled water, pH 7.4]. Erysipelothrix was grown in the same medium supplemented with glucose $\left(2 \mathrm{mg} \mathrm{ml}^{-1}\right)$ and haematin $\left(5 \mu \mathrm{g} \mathrm{ml}^{-1}\right)$ in static culture for $2 \mathrm{~d}$ at $30^{\circ} \mathrm{C}$. Cultures were checked for purity at maximum growth, killed with formaldehyde $(1 \%, v / v)$, harvested by centrifuging $(4750 \mathrm{~g}$ for $30 \mathrm{~min})$, washed with distilled water and freeze-dried.

Extraction, purification and analysis of isoprenoid quinones. Isoprenoid quinones were extracted and purified as described by Collins et al. (1977) and were further examined by reverse phase partition chromatography using Whatman $\mathrm{KC}_{18} \mathrm{~F}$ reverse phase thin-layer plates $(7.6 \times 7.6 \mathrm{~cm} ; 200 \mu \mathrm{m}$ thick) and a polar developing mixture of acetone/water $(97: 3, \mathrm{v} / \mathrm{v})$, separated components being detected with $254 \mathrm{~nm}$ ultraviolet light. Ultraviolet spectra of the quinones were recorded in iso-octane solution on a Perkin-Elmer (Model 137 UV) spectrophotometer. Mass spectra of the isoprenoid quinones were recorded on an AFI MS9 instrument using a direct insertion probe, an ionizing voltage of $70 \mathrm{eV}$ and a temperature range of 200 to $220{ }^{\circ} \mathrm{C}$.

\section{RESULTS}

Neither menaquinones (vitamin K) nor ubiquinones (coenzyme Q) were detected in E. rhusiopathiae, NCTC 8163. Components that co-chromatographed with vitamin $\mathrm{K}_{1}$ were the only isoprenoid quinones detected in representatives of the genera Brochothrix, Caryophanon and Listeria. Ultraviolet spectra of the isoprenoid quinones showed absorption maxima at 242, 248, 260, 270 and $326 \mathrm{~nm}$, in accord with published data for menaquinones (Dunphy \& Brodie, 1971).

The mass spectra of all the menaquinone samples showed intense peaks at $m / e 187$ and 
Table 1. Peaks corresponding to molecular ions in the mass spectra of menaquinones isolated from the test strains

The main component in each series is denoted by +++ , any component greater than $50 \%$ of the main peak by ++ , and all other significant components by + .

$$
\begin{gathered}
\text { Menaquinone isoprenologue } \\
\mathrm{m} / \mathrm{e}
\end{gathered}
$$

Brochothrix thermosphacta ATCC 11509*

Brochothrix thermosphacta $24 \uparrow$

Brochothrix thermosphacta $\mathbf{P} 2 \dagger$

Caryophanon tenue

Listeria grayi

Listeria grayi

Listeria monocytogenes

Listeria monocytogenes

Listeria monocytogenes

Listeria murrayi

Listeria murrayi

Listeria denitrificans

NCIB 9535

ATCC 19120

ATCC 25400

NCTC $10357^{*}$

NCTC 4885

NCTC 4883

ATCC 25402

ATCC 25403

L26*
MK-7
648
+++
+++
+++
-
+++
+++
+++
+++
+++
+++
+++
+

$\begin{array}{cc}\text { MK-8 } & \text { MK-9 } \\ 716 & 784\end{array}$

- -

$-$

$-\quad-$

- $\quad-$

- $\quad-$

$-\quad-$

- $\quad-$

- $\quad-$

$\bar{t}+\bar{t}+$

Erysipelothrix rhusiopathiae NCTC $8163^{*}$ did not contain isoprenoid quinones

* Type strain.

$\dagger$ From Dr G. A. Gardner, Ulster Curer's Association, 2 Greenwood Avenue, Belfast, N. Ireland.

$\ddagger$ From Pasteur Institute, Paris, France.

225 derived from the naphthaquinone nucleus, as expected from published data (Azerad \& Cyrot-Pelletier, 1973). Strong peaks corresponding to molecular ions $\left(\mathrm{M}^{+}\right)$were also observed. Details of the mass spectral analyses are shown in Table 1.

Caryophanon tenue contained unsaturated menaquinones with six isoprene units (abbreviated as MK-6, see Biochemical Journal, 1975, 147, 15-21, for standard nomenclature and abbreviations) as the predominant isoprenologue, although smaller amounts of MK-5 were also detected in the mass spectrum and on reverse phase chromatography. Brochothrix thermosphacta, L. grayi, L. monocytogenes and L. murrayi all contained MK-7 as the major isoprenologue, whereas $L$. denitrificans contained MK-9 as the major component.

\section{DISCUSSION}

The absence of isoprenoid quinones in E. rhusiopathiae distinguishes it from the other bacteria examined and is in accord with the absence of catalase and cytochromes in this taxon (Seeliger, 1974). Lactobacillus strains are also generally regarded as being incapable of synthesizing menaquinones (Dunphy \& Brodie, 1971).

The presence of MK-6 as the major isoprenologue in Caryophanon tenue is of particular interest because such short-chain menaquinones have not, to our knowledge, been noted as major components in other Gram-positive bacteria. Although at present this observation sheds little light on the taxonomic relationships of Car. tenue, it could prove of value when more information is available on the menaquinones of other Gram-positive asporogenous rods.

The similarity in the menaquinone profiles of $L$. monocytogenes, L. grayi and L. murrayi is further evidence of the close relationship between these taxa (Wilkinson \& Jones, 1977) but does not resolve the problem of whether $L$. grayi and $L$. murrayi should be reclassified in the genus Murraya as proposed by Stuart \& Welshimer (1974) or retained in the genus Listeria as maintained by Wilkinson \& Jones (1977). The recovery of MK-9 as the major isoprenoid quinone in L. denitrificans supports the view that this taxon should be removed from the genus Listeria (Stuart \& Welshimer, 1973; Jones, 1975a,b). 
The marked distinction between the menaquinone pattern of $B$. thermosphacta and that reported for $M$. lacticum (Collins et al., 1979), the type species of the genus Microbacterium, provides additional evidence for the recognition of the new genus Brochothrix (Sneath $\&$ Jones, 1976). Furthermore, the closely related menaquinone profiles of $B$. thermosphacta, L. monocytogenes, $L$. grayi and $L$. murrayi is in accord with the affinity between these taxa as demonstrated by other studies (Wilkinson \& Jones, 1977; Collins-Thompson et al., 1972; Stuart \& Welshimer, 1973; Schleifer, 1970; Schleifer \& Kandler, 1972; Raines et al., 1968; Shaw \& Stead, 1970; Tadayon \& Carroll, 1971). The menaquinone data together with the presence of predominantly straight-chain and methyl-branched fatty acids within Brochothrix and Listeria casts serious doubt on the proposal of Wilkinson \& Jones (1977) to include these two genera in an extended family Lactobacillaceae. However, further studies are required to clarify the higher taxonomic relationships of the genera Brochothrix and Listeria.

M. D. C. and D. J. thank the Medical Research Council for support (grant G977/613).

\section{REFERENCES}

Azerad, R. \& Cyrot-Pelletier, M. O. (1973). Structure and configuration of the polyprenoid side chain of dihydromenaquinones from mycoand corynebacteria. Biochimie 55, 591-603.

Breed, R. S., Murray, E. G. D. \& SMith, N. R. (editors) (1957). Bergey's Manual of Determinative Bacteriology, 7th edn. London: Baillière, Tindall \& Cox.

Brodie, A. F. \& Watanabe, T. (1966). Mode of action of vitamin $\mathrm{K}$ in micro-organisms. Vitamins and Hormones 24, 447-463.

Búchanan, R. E. \& Gibbons, N. E. (editors). (1974). Bergey's Manual of Determinative Bacteriology, 8th edn. Baltimore: Williams \& Wilkins.

Collins, M. D., Pirouz, T., Goodfellow, M. \& MINNIKIN, D. E. (1977). Distribution of menaquinones in actinomycetes and corynebacteria. Journal of General Microbiology 100, 221-230.

Collins, M. D., Goodfellow, M. \& Minnikin, D. E. (1979). Isoprenoid quinones in the classification of coryneform and related bacteria. Journal of General Microbiology 110, 127-136.

Collins-Thompson, D. L., Sørhaug, T., Witter, L. D. \& ORDAL, Z. J. (1972). Taxonomic consideration of Microbacterium lacticum, Microbacterium flavum and Microbacterium thermosphactum. International Journal of Systematic Bacteriology $22,65-72$.

Davidson, C. M. \& Hartree, E. F. (1968). Cytochrome as a guide to classifying bacteria; taxonomy of Microbacterium thermosphactum. Nature, London 220, 502-504.

Davidson, C. M., Mobis, P. \& Stubis, J. M. (1968). Some morphological and physiological properties of Microbacterium thermosphactum. Journal of Applied Bacteriology 31, 531-559.

Davis, G. H. G., Fomin, L., Wilson, E. \& Newton, K. G. (1969). Numerical taxonomy of Listeria, streptococci and possibly related bacteria. Journal of General Microbiology 57, 333-348.

DuNPHY, P. J. \& BRoDIE, A. F. (1971). The structure and function of quinones in respiratory metabolism. Methods in Enzymology 18, 407-461.
Flossmann, K. D. \& ErLer, W. (1972). Serologische, chemische und immunochemische Untersuchungen an Rotlaufbakterien. XI. Isolierung und Charakterisierung von Deoxyribonukleinsäuren aus Rotlaufbakterien. Archiv für experimentelle Veterinärmedizin 26, 817-824.

Friedman, M. E. \& ALM, W. L. (1962). Effect of glucose concentration in the growth medium on some metabolic activities of Listeria monocytogenes. Journal of Bacteriology 84, 375-376.

JoNES, D. (1975a). A numerical taxonomic study of coryneform and related bacteria. Journal of General Microbiology 87, 52-96.

JoNes, D. $(1975 b)$. The taxonomic position of Listeria. In Problems of Listeriosis, pp. 4-17. Edited by $\mathbf{M}$. Woodbine. Leicester: Leicester University Press.

KEDDIE, R. M. (1978). What do we mean by coryneform bacteria? In Coryneform Bacteria, pp. 1-12. Edited by I. J. Bousfield \& A. G. Callely. London: Academic Press.

MaNN, S. (1969). Uber die Zellwandbausteine von Listeria monocytogenes und Erysipelothrix rhusiopathiae. Zentralblatt für Bakteriologie, Parasitenkunde, Infektionskrankheiten und Hygiene (Abteilung $I$, Originale) 209, 510-522.

McLean, R. A. \& Sulzbacher, W. L. (1953). Microbacterium thermosphactum, spec.nov.; a nonheat resistant bacterium from fresh pork sausages. Journal of Bacteriology 65, 428-433.

MeYer, D. J. \& Jones, C. W. (1973). Distribution of cytochromes in bacteria: relationship to general physiology. International Journal of Systematic Bacteriology 23, 459-467.

Minnikin, D. E., Collins, M. D. \& Goodfellow, M. (1978a). Menaquinone patterns in the classification of nocardioform and related bacteria. Zentralblatt für Bakteriologie, Parasitenkunde, Infektionskrankheiten und Hygiene (Abteilung I), Supplement 6, 85-90.

Minnikin, D. E., Goodfellow, M. \& Collins, M. D. $(1978 b)$. Lipid composition in the classification and identification of coryneform and 
related taxa. In Coryneform Bacteria pp. 85-160. Edited by I. J. Bousfield \& A. G. Callely. London: Academic Press.

Raines, L. J., Moss, C. W., Farshtchi, D. \& PitTMAN, B. (1968). Fatty acids of Listeria monocytogenes. Journal of Bacteriology 96, 2175-2177.

REDfearn, E. R. (1966). Mode of action of ubiquinones (coenzyme $Q$ ) in electron transport systems. Vitamins and Hormones 24, 465-488.

SCHLEIFER, K. H. (1970). Die Mureintypen in der Gattung Microbacterium. Archiv für Mikrobiologie 71, 271-282.

Schleifer, K. H. \& Kandler, O. (1972). Peptidoglycan types of bacterial cell walls and their taxonomic implications. Bacteriological Reviews 36, 407-477.

SEeliger, H. P. R. (1974). Erysipelothrix. In Bergey's Manual of Determinative Bacteriology, 8th edn. pp. 597-598. Edited by R. E. Buchanan \& N. E. Gibbons. Baltimore: Williams \& Wilkins.

Seeliger, H. P. R. \& Welshimer, H. J. (1974). Listeria. In Bergey's Manual of Determinative Bacteriology, 8th edn. pp. 593-596. Edited by R. E. Buchanan \& N. E. Gibbons. Baltimore: Williams \& Wilkins.

Shaw, N. \& STEAd, D. (1970). A study of the lipid composition of Microbacterium thermosphactum as a guide to its taxonomy. Journal of Applied Bacteriology 33, 470-473.

SNEATH, P. H. A. \& Jones, D. (1976). Brochothrix, a new genus tentatively placed in the family
Lactobacillaceae. International Journal of Systematic Bacteriology 26, 102-104.

Stuart, M. R. \& Pease, P. E. (1972). A numerical study of the relationships of Listeria and Erysipelothrix. Journal of General Microbiology 73, 551-565.

Stuart, S. E. \& Welshimer, H. J. (1973). Intrageneric relatedness of Listeria Pirie. International Journal of Systematic Bacteriology 23, 8-14.

Stuart, S. E. \& Welshimer, H. J. (1974). Taxonomic re-examination of Listeria Pirie and transfer of Listeria grayi and Listeria murrayi to a new genus Murraya. International Journal of Systematic Bacteriology 24, 177-185.

TAdayon, R. A. \& Carroll, K. K. (1971). Effect of growth conditions on the fatty acid composition of Listeria monocytogenes and comparison with fatty acids of Erysipelothrix and Corynebacterium. Lipids 6, 820-825.

WHITTENBURY, R. (1978). Biochemical characteristics of Streptococcus species. In Streptococci, pp. 51-69. Edited by F. A. Skinner \& L. B. Quesnel. London: Academic Press.

Wilkinson, B. J. \& Jones, D. (1977). A numerical taxonomic survey of Listeria and related bacteria. Journal of General Microbiology 98, 399-421.

Yamada, Y., InOUye, G., Tahara, Y. \& Kondo, K. (1976). The menaquinone system in the classification of coryneform and nocardioform bacteria and related organisms. Journal of General and Applied Microbiology 22, 203-214. 